\title{
Acid and ultrasound assisted modification of boron enrichment process waste and using for methylene blue removal from aqueous solutions
}

\author{
Oden M.K. ${ }^{1}$ and Kucukcongar S. ${ }^{2}$ \\ ${ }^{1}$ Selcuk University, Sarayonu V.H.S., Department of Environmental Protect Tecnology, Sarayonu/Konya-TURKEY \\ ${ }^{2}$ Selcuk University, Eng. Fac., Department of Environmental Eng., 42031/Konya-TURKEY \\ Received: 28/10/2017, Accepted: 31/01/2018, Available online: 16/05/2018 \\ *to whom all correspondence should be addressed: e-mail:muhammedkoden@selcuk.edu.tr
}

\begin{abstract}
In this study, raw boron enrichment waste was treated with hydrochloric acid and ultrasound at $35-\mathrm{kHz}$ frequency for 60 minutes. To optimize the adsorption conditions for removal of methylene blue (MB) from synthetic wastewaters using raw boron enrichment waste (BEW), acid modified boron enrichment waste (HBEW) and ultrasound modified BEW (UBEW) by adsorption process and to compare the adsorption efficiency of chemical and ultrasonic modifications of BEW were aimed. The optimum adsorption conditions were determined economically and eco-friendly aspect and $\mathrm{MB}$ removal percents were found as $80 \%, 80 \%$ and $92 \%$ at optimum conditions for BEW, HBEW and UBEW, respectively. The maximum regression coefficient values were obtained as $0.911,0.998$ and 0.984 for BEW, HBEW and UBEW, respectively at Langmuir isotherm model. The adsorption rate was fitted well to pseudo-second order kinetics according to a good correlation coefficient. The adsorption of $\mathrm{MB}$ onto adsorbents studied is spontaneous in nature and feasible because of negative $\Delta G$ values. The results indicated that the boron enrichment process waste could be a suitable adsorbent for removal of $\mathrm{MB}$ from aqueous solution. The maximum adsorption capacities were equal to about 107,0 $\mathrm{mg} / \mathrm{g}, 160,7 \mathrm{mg} / \mathrm{g}$ and $145,3 \mathrm{mg} / \mathrm{g}$ for BEW, HBEW and UBEW adsorbents at $298 \mathrm{~K}$, respectively. The maximum dye removal percent was achieved for UBEW as $92 \%$ and ultrasound assisted modification was found more efficient method compared with acidic modification for $M B$ removal.
\end{abstract}

Keywords: Adsorption, methylene blue, boron enrichment process waste, aqueous solution, adsorbents.

\section{Introduction}

The contamination of wastewater by synthetic dyes is an important problem (Anbia, Hariri et al., 2010, Kaur, Rani et al., 2015). Synthetic dyes are preferred because of color availability, easy to use, persistent, quick-setting compared with natural dyes (Chowdhury and Saha 2010; Kurniawan, Sutiono et al., 2012). Large volumes of colored effluents including hazardous substances for human health and natural ecosystems generate from several industries that need to be effectively treated (Christie, 2007; Petrucci, Di Palma et al., 2015). The release of these wastewaters in the environment is a significant source of visual pollution, eutrophication and serious environmental impacts because of highly toxic components. Nowadays, thermally stable dyes are introduced which are difficult to degrade after use. Therefore, suitable treatment of these wastewaters prior to discharge into receiving streams has drawn increasing attention (Panizza and Cerisola, 2008). To remove the dyes used different industries are difficult by conventional wastewater treatment plants since they are resistant to chemical oxidation, light and microbial digestion (Extremera, Pavlovic et al., 2012). Various treatment techniques have been applied for the removal of dyes from aqueous solutions. Adsorption (Bousher, Shen et al., 1997), electrolysis (Gupta, Ali et al., 2012) coagulation (Bache, Hossain et al., 1991), chemical oxidation with different material (Muthukumar, Sargunamani et al., 2004), fenton (Karthikeyan, Gupta et al., 2012), degradation (Saravanan, Karthikeyan et al., 2013), photodegradation (Gupta, Jain et al., 2011; Gupta, Jain et al., 2012; Saleh and Gupta, 2012; Saravanan, Karthikeyan et al., 2013; Rajendran, Khan et al., 2016) are frequently employed methods for dye removal. Adsorption is most preferable method because of low energy consumption and cost, easy availability and design criteria for wide range of dye concentration and high efficiency (Meshko, Markovska et al., 2001, Sanghi and Bhattacharya, 2002). Besides everything the success of the adsorption process relates primarily on the type of the dye and of the wastewater variety. A number of natural adsorbents were examined for the treatment of dyes, such as clays as an alternative to activated carbon to decrease the operation costs (Gupta, Srivastava et al., 1997, Kannan and Sundaram, 2001). In recent years, various types of waste materials were applied as adsorbent for dye removal such as ash (Janoš, Buchtová et al., 2003, Mittal, Mittal et al., 2009), blast furnace dust (Jain, Gupta et al., 2003), fertilizer waste (Gupta, Srivastava et al., 1998, Jain, Gupta et al., 
2003), slag (Ramakrishna and Viraraghavan, 1997, Gupta, Ali et al., 2003), agricultural residues materials (Mittal, Krishnan et al., 2005; Mittal, Mittal et al., 2010, Ahmaruzzaman and Gupta, 2011; Gupta and Nayak, 2012), waste tea (Gokce and Aktas, 2014), lubrication oil/palm waste (AlOthman, Habila et al., 2014), potato plant waste (Gupta, Kushwaha et al., 2016), rice husk (Sharma, Kaur et al., 2010), cotton waste (Ertaş, Acemioğlu et al., 2010), phosphate rock (Malash and El-Khaiary, 2010), citrus limetta peel waste (Shakoor and Nasar, 2016) and red mud (Gupta, Suhas et al., 2004) etc.

The boron ores are important natural resources in Turkey. Because of Turkey has large scale of boron reserves, a large amount of boron enrichment process waste (also known as borate waste/boron containing waste) is discharged from the boron plants during enrichment process and can cause disposal problem environmentally. Boron enrichment process waste, the source of which is essentially the extractive activity (concentrator waste), has a rather broad phase composition (Cicek, Esposito et al., 2012). The use of boron ore waste as an adsorbent is reasonable because of ulexite, calcite, dolomite, zeolite and some clays contents and low cost of these wastes (Olgun and Atar, 2009; Atar, Olgun et al., 2011). The efficiency of the adsorption method depends primarily on the structure of the dye (Abo-Elela and El-Dib, 1987).

Modification of waste with ultrasound is an environmentally friendly method and reduces the chemicals usage, waste production and energy consumption compared with other chemical modification methods (Sujka, 2017). In this study, raw boron enrichment waste (BEW), modified boron enrichment waste with hydrochloric acid (HBEW) and modified boron enrichment waste with ultrasound (UBEW) were used as adsorbent for removal of $\mathrm{MB}$ from synthetic wastewater. The novelty bought by these adsorbent is the improvement in keeping dye pigments, thereby enhancing more dye removal efficiency. The process was examined for different initial adsorbent dosage, temperature, $\mathrm{pH}$ and agitation speed to determine the optimum equilibrium conditions.

\section{Materials and methods}

\subsection{Adsorbents, Dyestuff and Reagents}

Methylene blue is a basic, cationic dye (molecular formula $\mathrm{C}_{16} \mathrm{H}_{18} \mathrm{ClN}_{3} \mathrm{~S} \cdot 3 \mathrm{H}_{2} \mathrm{O}$ and molecular weight $373.90 \mathrm{~g} \mathrm{~mol}^{-1}$ ) with CAS No. 61-73-4. The chemical structure of the dye is shown in Figure 1.

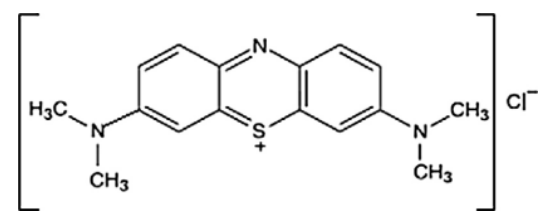

Figure 1. Chemical structure of methylene blue (Khosravi and Eftekhar, 2014)

A stock methylene blue solution $(1000 \mathrm{mg} / \mathrm{L})$ was prepared and diluted with distilled water to obtain various initial concentrations for adsorption experiments. The concentration of $\mathrm{MB}$ in synthetic wastewater was measured on DR-2800 model UV-VIS spectrophotometer (Hach Lange, Germany) at $\lambda_{\max }$ of $661 \mathrm{~nm}$ wavelength.

The raw BEW, HBEW and UBEW were used as adsorbents for methylene blue removal from water in this study. BEW formed during boron enrichment process was supplied from Etibor Colemanite and Ulexite Production Plant (Eti Mine Works General Directorate Bigadiç Boron Works Management Offices, Balikesir, Turkey). BEW was dried in oven at $103{ }^{\circ} \mathrm{C}$ and then stored in desiccator until to use. Acid-modified boron enrichment waste (HBEW) was treated with hydrochloric acid for to increase the activated surface of adsorbent. The ultrasonic modification process was performed in water bath at $35-\mathrm{kHz}$ ultrasonic frequency approximately 60 minutes.

Batch adsorption experiments were performed in flasks on a thermal shaker. Investigation the effect of different parameters on $\mathrm{MB}$ adsorption was followed according to adsorbent dose, contact time, shaking speed and $\mathrm{pH}$. The dye concentrations $\left(\mathrm{mg} \mathrm{L}^{-1}\right)$ at the beginning $\left(C_{0}\right)$ and equilibrium $\left(C_{e}\right)$ of the experiments were determined and dye removal percent was calculated according to Eq. (1):

dye removal $(\%)=\left[\frac{\left(C_{o}-C_{e}\right)}{C_{0}}\right] \times 100$

The equilibrium adsorption capacity was determined by the following equation:

$$
q e=\left[\frac{\left(C_{0}-C_{e}\right)}{W} \times v\right]
$$

where $\mathrm{q}_{\mathrm{e}}$ is the amount of dye adsorbed at time $\mathrm{t}$ ( $\mathrm{mg} \mathrm{g}^{-1}$ adsorbent); $\mathrm{W}$ is the adsorbent mass ( $\mathrm{g}$ ) and $\mathrm{V}$ is the volume of the solution (L).

The $\mathrm{pH}$ measurements were performed using Hach MultiHQ40d Instrument. A ZHWY-200B model (ZHICHENG Analytical Co., Ltd) thermal stirrer was used for the batch experiments. The solutions were filtered through $0.45-\mu \mathrm{m}$ membrane filters (Millipore Corp., Bedford, Mass.) at the end of the experiments and then analyzed using UV-VIS spectrometer (Hach Lange DR 2800).

\section{Results and discussion}

\subsection{Adsorbents}

Chemical compositions of raw BEW, HBEW and UBEW samples were determined by using SEM spectrometer. Major chemical constituents of BEW, BEW and UBEW are given in Figure 2.

The highest porosity was observed at UBEW surface as shown in Figure 2. Surface of boron enrichment waste modified with ultrasound has more numerous and smaller pores than surfaces of BEW and HBEW. Potato, rice, wheat and corn starches surfaces were treated with ultrasound in literature and it was found that ultrasound treatment caused significant change of specific surface area of all studied starches and new pores were formed at 1.7-300 nm range (Sujka, 2017). In other study, chitin surface was modified with ultrasound and surface area of ultrasonic 
modified chitin was found higher than raw chitin (Dotto, Santos et al,. 2015). Under high thermodynamic conditions, adsorbent surface was modified by forces to cavities formed in the liquid, supported by the hot spot theory

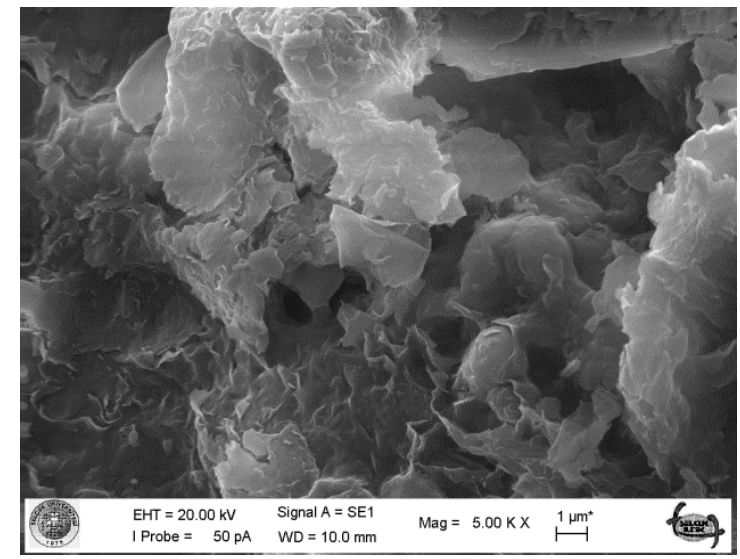

(a)
(Dotto, Santos et al., 2015). The surface activity and adsorption capacity will increase with the increasing of surface porosity.

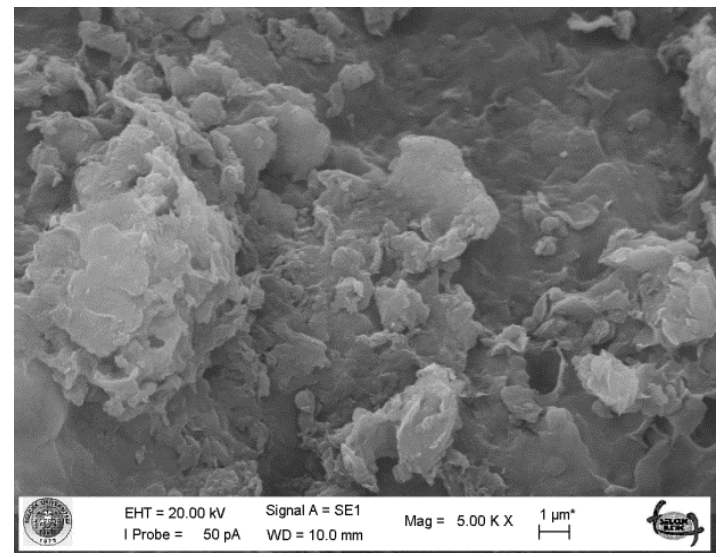

(b)

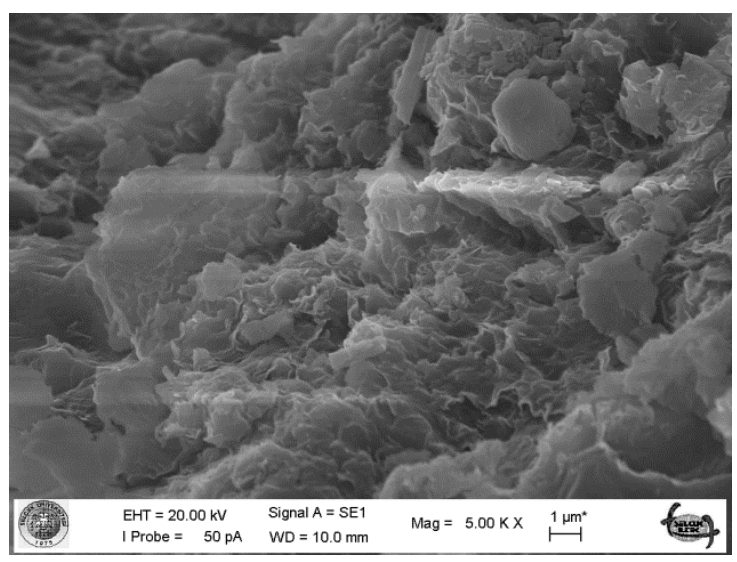

(c)

Figure 2. Scanning electron microscope images of (a) BEW, (b) HBEW and (c) UBEW

\subsection{Effect of adsorbent dosage, contact time and stirring speed}

$M B$ removal was performed using $B E W, H B E W$ and UBEW as adsorbents from synthetic wastewaters containing 100 $\mathrm{mg} / \mathrm{L}$ stock MB at initial adsorbent dose 250-2000 mg/L, temperature $25^{\circ} \mathrm{C}$, original $\mathrm{pH}$ value 5-6.5 range, shaking speed $200 \mathrm{rpm}$ and contact time $0-150$ minutes. The results of experimental studies for to determine the optimum adsorption conditions at different contact time and adsorbent dose were given in Figure 3.

The optimum conditions were selected as economically aspect and applicability in field. It was obtained that color removal was $70 \%$ for $\mathrm{BEW}$ at 40 minute contact time and $750 \mathrm{mg} / \mathrm{L}$ initial adsorbent dose. MB removal was determined as $72 \%$ for HBEW at 30 minute contact time and $500 \mathrm{mg} / \mathrm{L}$ initial adsorbent dose. The optimum MB removal was achieved as $75 \%$ for UBEW at 40 minute contact time for $625 \mathrm{mg} / \mathrm{L}$ adsorbent dose. El Haddad, (2015) found that the maximum adsorption of Basic Fuchsin is observed at $60 \mathrm{~min}$ for all dye concentrations (EI Haddad, 2015). In other study, the maximum removal efficiency was obtained as $80.4 \%$ at equilibrium time 10 min and adsorbent dose $0.25 \mathrm{~g} / \mathrm{L}$ in batch optimization studies (Muthukumaran, Sivakumar et al., 2016). The removal of methylene blue with montmorillonite clay was obtained at 30 minutes by (Almeida, Debacher et al., 2009) and the equilibrium was achieved at $120 \mathrm{~min}$ for remove Basic Green 4 with by Sea shell powder (Chowdhury and Saha, 2010).

The dye removal percent increased with the increasing dose of adsorbent. Similar results have also been reported in other studies and predicated to the more adsorbent surface area and availability of adsorption sites (Ertaş, Acemioğlu et al., 2010). Fig. 3 indicates that the adsorption efficiency for the BEW, HBEW, and UBEW were increased rapidly first 30-40 min contact time and then process was reached to equilibrium. This may be according to the availability of abundant sites on adsorbent surface or to bind the MB at initial stages (Gobi, Mashitah et al., 2011). At the same time, higher initial MB concentrations from $750 \mathrm{mg} / \mathrm{L}$ didn't affected to dye removal efficiency due to the absence of abundant sites of adsorbent surface. 

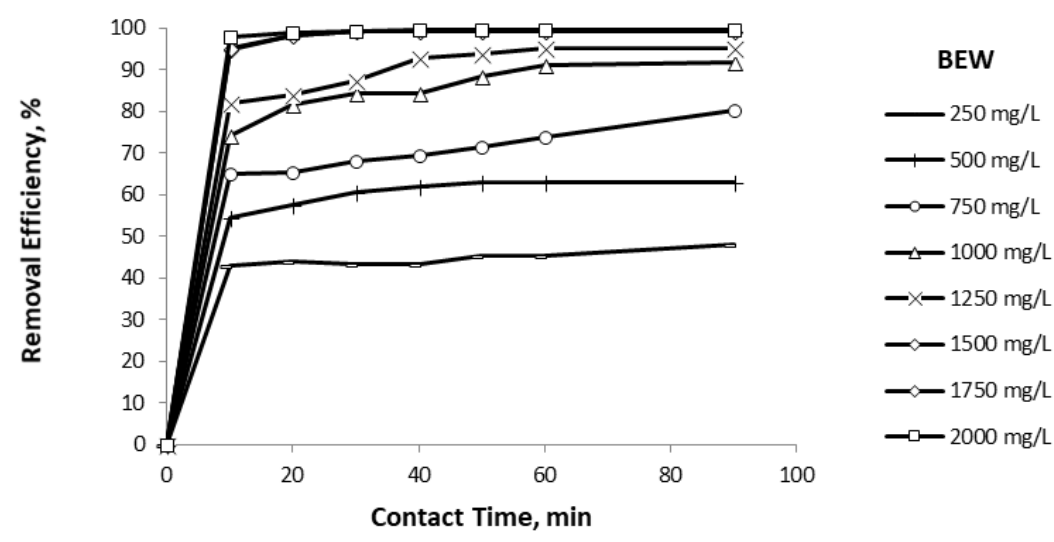

(a)

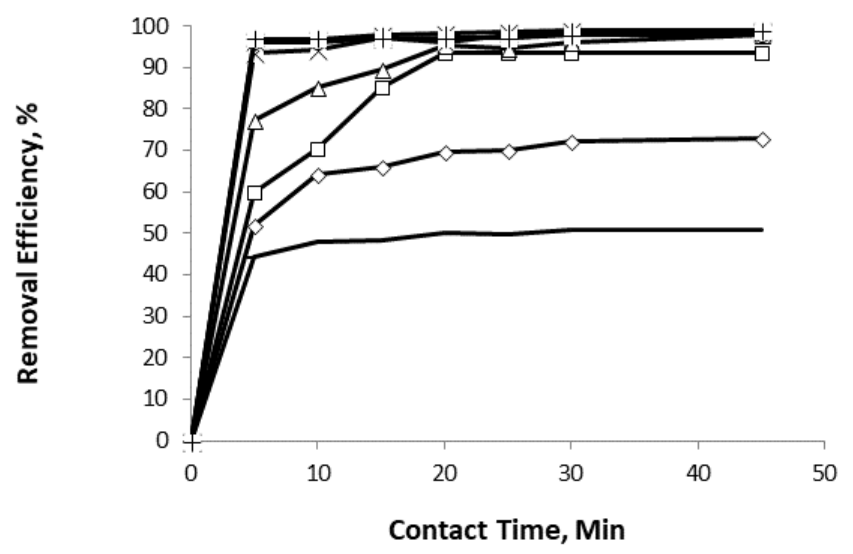

HBEW

$250 \mathrm{mg} / \mathrm{L}$

$\longrightarrow 500 \mathrm{mg} / \mathrm{L}$

$\longrightarrow-750 \mathrm{mg} / \mathrm{L}$

$\longrightarrow 1000 \mathrm{mg} / \mathrm{L}$

$-\times-1250 \mathrm{mg} / \mathrm{L}$

- $-1500 \mathrm{mg} / \mathrm{L}$

$\longrightarrow-1750 \mathrm{mg} / \mathrm{L}$

$-1-2000 \mathrm{mg} / \mathrm{L}$

(b)

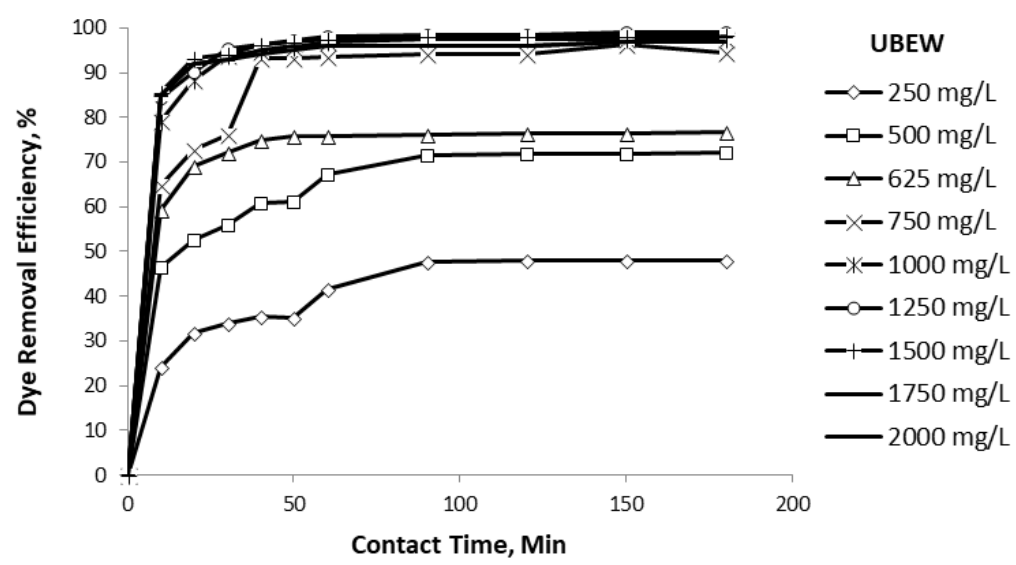

(c)

Figure 3. Effects of contact time and adsorbent dose on MB removal efficiency for a) BEW b) HBEW c) UBEW (Initial conditions $=\mathrm{pH}: 5-6$, temperature: 298 Kelvin, dye concentration: $100 \mathrm{mg} / \mathrm{L}$, shaking speed: $200 \mathrm{rpm}$ ).

$\mathrm{MB}$ dye removal increased with increasing contact time and initial dye concentration in other study (AlOthman, Habila et al., 2014) and it explained abundant of uncovered surface and active sites may be influenced to rapid adsorption at initial stages of batch experiments. Also the larger driving force to mass transfer resistance between liquid and dye was increased at higher initial dye concentrations (Gobi, Mashitah et al., 2011).
The effects of stirring speed on the removal of MB was investigated, for this purpose batch adsorption experiments were carried out with different adsorbents using different stirring speeds in the range of 100-400 rpm at $100 \mathrm{mg} \mathrm{L}^{-1}$ initial dye concentration. The adsorption values for the BEW, HBEW, and UBEW were lowest at 100 $\mathrm{rpm}$ and increased when the shaking speed increased to $200 \mathrm{rpm}$, then fixed slightly as speed increased to $400 \mathrm{rpm}$. 
When shaking speed was increased from 200 to $300 \mathrm{rpm}$, dye removal percent decreased at an insignificant level and the external mass transfer may be ineffective at higher stirring speed from $200 \mathrm{rpm}$. Therefore, the optimum stirring speed was accepted as $200 \mathrm{rpm}$. In literature, the flasks were agitated frequently at 150-200 rpm constant speed (Chowdhury and Saha, 2010).

\subsection{Effect of $p H$}

The initial values of synthetic wastewater for different adsorbents were adjusted in the 1-13 range. Dye removal efficiency for three adsorbents studied at different $\mathrm{pH}$ values were shown in Figure 4.

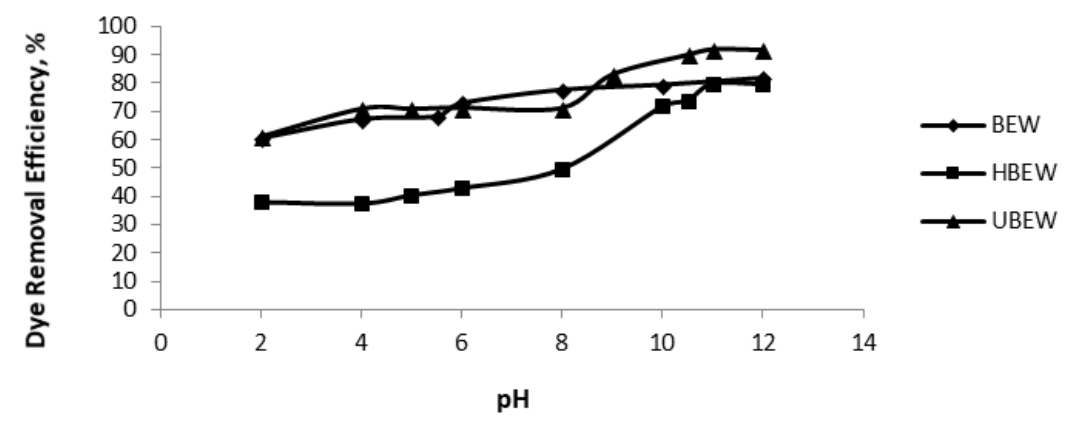

Figure 4. Effects of $\mathrm{pH}$ on MB removal efficiency for BEW, HBEW and UBEW (Initial Conditions; Dye Concentration: 100 $\mathrm{mg} / \mathrm{L}$, Speed:200 rpm, $298 \mathrm{~K}$ temperature)

$\mathrm{pH}$ optimization experiments were performed under the following adsorption conditions: Adsorbent dose: 750 $\mathrm{mg} / \mathrm{L}, 500 \mathrm{mg} / \mathrm{L}$ and $625 \mathrm{mg} / \mathrm{L}$ for BEW, HBEW and UBEW respectively; shaking speed: $200 \mathrm{rpm}$, temperature: $298 \mathrm{~K}$ $\left(25^{\circ} \mathrm{C}\right)$; contact time: 40 minute, 30 minute and 40 minute for BEW, HBEW and UBEW respectively. The percents of dye removal was achieved as $77 \%, 79 \%$ and $91 \%$ for $B E W$, HBEW and UBEW adsorbents at 8,11 and $11 \mathrm{pH}$ values, respectively.

Initial $\mathrm{pH}$ of solution is important for $\mathrm{MB}$ removal because of its impact on ionization of dye molecules and active groups of adsorbent surface. MB adsorption capacity increased when the initial $\mathrm{pH}$ increased and it explained that formation of negatively charged groups on surface of adsorbent at higher $\mathrm{pH}$ values (Sharma, Kaur et al., 2010, Auta and Hameed, 2011, AlOthman, Habila et al., 2014).

The optimum adsorption conditions were given in Table 1 for three adsorbents. Optimum MB removal efficiency was achieved for UBEW as $92 \%$. It can be seen that, BEW and HBEW show similar adsorption performance (approximately 80\%). There are different approaches for acidic modification of adsorbents for $M B$ removal performance in literature. Acidic modifications of surface of adsorbents increase oxygen content, weaken the dispersion forces and adsorption capacities. Another approach is acidic groups on adsorbent surface increase electrostatic attraction, molecular starking and locate of dye molecules vertically (Gokce and Aktas, 2014).

Table 1. Comparison of the optimum adsorption confitions of adsorbents for removal MB from aqueous media.

\begin{tabular}{lccc}
\hline Adsorbent & BEW & HBEW & UBEW \\
\hline Contact time, $\min$ & 40 & 30 & 40 \\
\hline Adsorbent dose, $\mathrm{mg} / \mathrm{L}$ & 750 & 500 & 625 \\
\hline $\mathrm{pH}$ & 8 & 11 & 11 \\
\hline Shaking speed, $\mathrm{rpm}$ & 200 & 200 & 200 \\
\hline Temperature, ${ }^{\circ} \mathrm{C}$ & 25 & 25 & 25 \\
\hline MB removal & 80 & 80 & 92 \\
\hline
\end{tabular}

\subsection{Determination of adsorption isotherms}

An adsorption isotherm is important to characterize the adsorbent-adsorbate relation and Langmuir, Freundlich and Tempkin isotherm models are commonly used for this purpose (Chabani, Amrane et al., 2006, Serpen, Ataç et al.,
2007, Wang, Ying et al., 2012). The adsorption of dye onto each of the three adsorbents was studied at all three temperatures, respectively 25,35 , and $45^{\circ} \mathrm{C}$. Langmuir, Freundlich and Temkin adsorption isotherm constants were calculated and given in Table 2 .

Table 2. Estimated constants of Langmuir, Freundlich and Temkin isotherms for MB removal by BEW, HBEW and UBEW.

\begin{tabular}{cccccccccc}
\hline & \multicolumn{3}{c}{ Freundlich isotherm } & \multicolumn{3}{c}{ Langmuir isotherm } & \multicolumn{3}{c}{ Temkin isotherm } \\
\hline & $\mathbf{K f}$ & $\mathbf{n}$ & $\mathbf{R}^{\mathbf{2}}$ & $\boldsymbol{b}(\boldsymbol{a L}) \mathbf{~ m g} / \mathbf{g})$ & $\boldsymbol{K L}(\mathbf{L} / \mathbf{m g})$ & $\mathbf{R}^{\mathbf{2}}$ & $\mathbf{K T}$ & at & $\mathbf{R}^{\mathbf{2}}$ \\
\hline BEW & 1,358 & 0,605 & 0,295 & 0,086 & 0,174 & 0,911 & 0,503 & 16,245 & 0,512 \\
\hline HBEW & 39,994 & 0,91 & 0,365 & 0,081 & 20,408 & 0,998 & 44,15 & 1,661 & 0,966 \\
\hline UBEW & 57,016 & 0,792 & 0,255 & 0,750 & 125,000 & 0,984 & 25,75 & 245,635 & 0,833 \\
\hline
\end{tabular}


It was seen that the data fitted well to Langmuir isotherm model for the temperature and dye concentration range studied. The maximum regression coefficient values were obtained as 0.911, 0.998 and 0.984 for BEW, HBEW and UBEW, respectively at Langmuir isotherm model. This indicates that the adsorption of $\mathrm{MB}$ on these three adsorbents takes place as monolayer adsorption on a surface of adsorbent is homogeneous in adsorption affinity (Malash and El-Khaiary, 2010). Similar results were found in other studies (Lee, Kim et al., 2011),(Tang, Zhou et al., 2012). The adsorption capacity of different adsorbents is given in Table 3.

Table 3. The comparison of experimental sorption capacities of BEW, HBEW and UBEW to some sorbents for methylene blue sorption

\begin{tabular}{|c|c|c|c|}
\hline Adsorbents & Dyes & $q, \mathrm{mg} / \mathrm{g}$ & References \\
\hline $\begin{array}{l}\text { Chemical Modified Apricot Stones, } \\
\text { Microwave Modified Apricot Stones }\end{array}$ & Methylene Blue & $\begin{array}{c}95,24 \\
126,58\end{array}$ & (Namal and Kalipci, 2017) \\
\hline $\begin{array}{l}\text { Cotton Stalk, } \\
\text { Cotton Waste, } \\
\text { Cotton Dust }\end{array}$ & Methylene Blue & $\begin{array}{l}5,95 \\
14,04 \\
15,78\end{array}$ & (Ertaş, Acemioğlu et al., 2010) \\
\hline $\begin{array}{l}\text { Palm Stem Waste/Lubricating Oil } \\
\text { Waste }\end{array}$ & Methylene Blue & 128,89 & (AlOthman, Habila et al., 2014) \\
\hline Potato Leaves Powder, PLP & $\begin{array}{l}\text { Methylene Blue, } \\
\text { Malachite Green }\end{array}$ & $\begin{array}{l}52,6 \\
33,3\end{array}$ & \multirow[b]{2}{*}{ (Gupta, Kushwaha et al., 2016) } \\
\hline Potato Stem Powder, PSP & $\begin{array}{l}\text { Methylene Blue, } \\
\text { Malachite Green }\end{array}$ & $\begin{array}{l}41,6 \\
27,0\end{array}$ & \\
\hline $\begin{array}{l}\text { Palm Oil Mill Effluent Waste Activated } \\
\text { Sludge }\end{array}$ & Methylene Blue & 66,23 & (Gobi, Mashitah et al., 2011) \\
\hline Waste Tea Activated Carbon & Methylene Blue & 554,30 & (Auta and Hameed, 2011) \\
\hline Modified Chitin & Methylene Blue & 26,69 & (Dotto, Santos et al., 2015) \\
\hline Citrus Limetta Peel Waste & Methylene Blue & 227,3 & (Shakoor and Nasar, 2016) \\
\hline $\begin{array}{l}\text { Boron Enrichment Waste (BEW), } \\
\text { Acid Modified BEW (HBEW), } \\
\text { Ultrasound Modified BEW (UBEW) }\end{array}$ & Methylene Blue & $\begin{array}{l}107,0 \\
160,7 \\
145,3\end{array}$ & This Study \\
\hline
\end{tabular}

\subsection{Adsorption thermodynamics}

For to determine the adsorption thermodynamic; In $\mathrm{K}_{\mathrm{c}}$ and $1 / T$ relations of equilibrium data at different temperature $\left(25^{\circ} \mathrm{C}, 35^{\circ} \mathrm{C}\right.$ and $\left.45^{\circ} \mathrm{C}\right)$ were investigated. The results of the experiments were given in Table 4. It can be seen that the adsorption process can occur spontaneously at the normal and high temperatures, because of enthalpy change, $\Delta H^{\circ}>0$, entropy change, $\Delta S^{\circ}>0$ and Gibb's energy change $\left(\Delta G^{\circ}\right)$ is negative.

Table 4. Thermodynamic parameters for the adsorption of MB onto BEW,HBEW and UBEW.

\begin{tabular}{|c|c|c|c|c|c|}
\hline & $T(K)$ & Inb & $\Delta G\left(\mathrm{~kJ} \mathrm{~mol}^{-1}\right)$ & $\Delta \mathrm{H}\left(\mathrm{kJ} \mathrm{mol}^{-1}\right)$ & $\Delta S\left(\mathrm{~kJ} \mathrm{~mol}^{-1} \mathrm{~K}^{-1}\right)$ \\
\hline & 298 & 1,417 & $-3,963$ & & \\
\hline \multirow[t]{3}{*}{ BEW } & 308 & 1,437 & $-3,725$ & 3,589 & 0,023 \\
\hline & 318 & 1,509 & $-3,963$ & & \\
\hline & 298 & 1,380 & $-3,414$ & & \\
\hline \multirow[t]{3}{*}{ HBEW } & 308 & 1,398 & $-3,587$ & 1,735 & 0,017 \\
\hline & 318 & 1,424 & $-3,760$ & & \\
\hline & 298 & 2,070 & $-5,159$ & & \\
\hline \multirow[t]{2}{*}{ UBEW } & 308 & 2,242 & $-5,687$ & 10,575 & 0,052 \\
\hline & 318 & 2,338 & $-6,215$ & & \\
\hline
\end{tabular}

\subsection{Adsorption kinetics}

Pseudo-first order, Pseudo-second order and intraparticle diffusion coefficient values for $M B$ removal from wastewaters using BEW, HBEW and UBEW were given in Table 5. Because of high correlation coefficients $\left(R^{2}=0.996\right.$ and 0.998$)$, the data fitted well to the model of pseudo second order kinetic. qehes values calculated for Pseudosecond order kinetic are similar with experimental $q_{e}$ values. Pseudo-second order kinetic is the best model for cationic dye removals and this model provided a more accurate and comprehensive reflection of the adsorption mechanism, because of explains the external liquid film diffusion, surface adsorption and intra-particle diffusion processes (Fan, Tang et al., 2016). This result is in agreement with many other studies of kinetics of adsorption of dyes (Özcan, Erdem et al., 2004, Kumar, 2007, El Boujaady, El Rhilassi et al., 2011). 
Table 5. Kinetic parameters for the adsorption of MB onto BEW,HBEW and UBEW.

\begin{tabular}{|c|c|c|c|c|c|c|c|c|c|}
\hline \multirow[b]{2}{*}{$\begin{array}{c}25^{\circ} \mathrm{C} \\
\text { (298 Kelvin) }\end{array}$} & \multicolumn{3}{|c|}{ Pseudo-first-order } & \multicolumn{3}{|c|}{ Pseudo-second-order } & \multicolumn{3}{|c|}{ Intra-particle diffusion } \\
\hline & $\mathrm{K}_{1}(1 / \mathrm{min})$ & $\mathbf{R}^{2}$ & $\mathrm{qe}_{\text {hes }}\left(\mathrm{mg} \mathrm{g}^{-1}\right)$ & $\begin{array}{c}K_{2} \\
\left(\min . g \mathrm{mg}^{-1}\right)\end{array}$ & $\mathbf{R}^{2}$ & $\mathbf{q e}_{\text {hes }}$ & $\begin{array}{c}\mathrm{K}_{\text {int }} \\
\left(\mathrm{mg} \mathrm{g}^{-1} \mathrm{~min}^{-}\right. \\
0.5)\end{array}$ & $\mathbf{R}^{2}$ & C \\
\hline BEW & 0,009 & 0,210 & 21,428 & 0,002 & 0,996 & 111,111 & 6,515 & 0,748 & 54,73 \\
\hline HBEW & 0,006 & 0,228 & 27,797 & 0,001 & 0,996 & 166,666 & 9,277 & 0,687 & 85,12 \\
\hline UBEW & 0,004 & 0,469 & 29,040 & 0,002 & 0,998 & 166,667 & 6,628 & 0,661 & 91,68 \\
\hline
\end{tabular}

\section{Conclusions}

This study focuses on the ability of raw and different modifications of boron enrichment waste as an adsorbent for removal of methylene blue dye from aqueous solutions. The operating criterions for the optimum color removal were dye solution concentration $(100 \mathrm{mg} / \mathrm{L})$, BEW, HBEW and UBEW sorbent dosage $(750 \mathrm{mg} / \mathrm{L} ; 500 \mathrm{mg} / \mathrm{L} ; 625$ $\mathrm{mg} / \mathrm{L}$ ), contact time (40 $\mathrm{min}, 30 \mathrm{~min}, 40 \mathrm{~min}$ ) respectively, and temperature $(298 \mathrm{~K})$. Removal of methylene blue dye is depends on $\mathrm{pH}$ and the maximum removal was achieved at $\mathrm{pH} 8,11$ and 11 for BEW, HBEW and UBEW, respectively. The maximum adsorption capacities were equal to about $107,0 \mathrm{mg} / \mathrm{g}, 160,7 \mathrm{mg} / \mathrm{g}$ and $145,3 \mathrm{mg} / \mathrm{g}$ for BEW, HBEW and UBEW adsorbents at $298 \mathrm{~K}$, respectively. Equilibrium data were investigated in the Langmuir, Freundlich and Tempkin isotherm models which detected that the sorption is heterogeneous and occurred through physicochemical interactions. The maximum regression coefficient values were obtained as $0.911,0.998$ and 0.984 for BEW, HBEW and UBEW, respectively at Langmuir isotherm model. The adsorption rate was found suited to pseudosecond order kinetics with high correlation coefficient. The adsorption of $\mathrm{MB}$ is feasible and spontaneous in nature because of negative $\Delta G$ values, according to thermodynamic study. The results indicated that the BEW, HBEW and UBEW could be a proper adsorbent for removal of $\mathrm{MB}$ from aqueous solution. It is believed that the results of this study will contribute to use of boron enrichment waste released from boron mineral processing plant in different disciplines. To use of industrial waste materials as secondary raw materials can be an alternative to the commercial activated carbon and would be beneficial for environmental sustainability.

\section{Acknowledgments}

This study was financially supported by Selcuk University Scientific Research Coordinating Office under grant no 13101005 . We also gratefully thank to Assoc. Prof. Dr. Celalettin OzDEMiR for supporting of this study.

\section{References}

Abo-Elela S.I. and El-Dib M.A. (1987), Color removal via adsorption on wood shaving, Science of The Total Environment, 66, 269-273.

Ahmaruzzaman M. and Gupta V.K. (2011), Rice Husk and Its Ash as Low-Cost Adsorbents in Water and Wastewater Treatment, Industrial and Engineering Chemistry Research, 50(24), 13589-13613.

Almeida C.A.P., Debacher N.A., Downs A.J., Cottet L. and Mello C.A.D. (2009), Removal of methylene blue from colored effluents by adsorption on montmorillonite clay, Journal of Colloid and Interface Science, 332(1), 46-53.

AlOthman Z.A., Habila M.A., Ali R., Abdel Ghafar A. and El-din Hassouna M.S. (2014), Valorization of two waste streams into activated carbon and studying its adsorption kinetics, equilibrium isotherms and thermodynamics for methylene blue removal, Arabian Journal of Chemistry, 7(6), 1148-1158.

Anbia M., Hariri S.A. and Ashrafizadeh S.N. (2010), Adsorptive removal of anionic dyes by modified nanoporous silica SBA-3, Applied Surface Science, 256(10), 3228-3233.

Atar N., Olgun A., Wang S. and Liu S. (2011), Adsorption of anionic dyes on boron industry waste in single and binary solutions using batch and fixed-bed systems, Journal of Chemical \& Engineering Data, 56(3), 508-516.

Auta M. and Hameed B.H. (2011), Optimized waste tea activated carbon for adsorption of Methylene Blue and Acid Blue 29 dyes using response surface methodology, Chemical Engineering Journal, 175(Supplement C), 233-243.

Bache D.H., Hossain M.D., Al-Ani S.H. and Jackson P.J. (1991), Optimum coagulation conditions for a coloured water in terms of floc size, density and strength, Water Supply, 9(1), 93-102.

Bousher A., Shen X. and Edyvean R.G. (1997), Removal of coloured organic matter by adsorption onto low-cost waste materials, Water Research, 31(8), 2084-2092.

Chabani M., Amrane A. and Bensmaili A. (2006), Kinetic modelling of the adsorption of nitrates by ion exchange resin, Chemical Engineering Journal, 125(2), 111-117.

Chowdhury S. and Saha P. (2010), Sea shell powder as a new adsorbent to remove Basic Green 4 (Malachite Green) from aqueous solutions: Equilibrium, kinetic and thermodynamic studies, Chemical Engineering Journal, 164(1), 168-177.

Christie R.M. (2007), Environmental aspects of textile dyeing, Elsevier.

Cicek B., Esposito L., Tucci A., Bernardo E., Boccaccini A. and Bingham P. (2012), Microporous glass ceramics from combination of silicate, borate and phosphate wastes, Advances in Applied Ceramics, 111(7), 415-421.

Dotto G.L., Santos J.M.N., Rodrigues I.L., Rosa R., Pavan F.A. and Lima E.C. (2015), Adsorption of Methylene Blue by ultrasonic surface modified chitin, Journal of Colloid and Interface Science, 446(Supplement C), 133-140.

El Boujaady H., El Rhilassi A., Bennani-Ziatni M., El Hamri R., Taitai A. and Lacout J.L. (2011), Removal of a textile dye by adsorption on synthetic calcium phosphates, Desalination, 275(1-3), 10-16.

El Haddad M. (2015), Removal of Basic Fuchsin dye from water using mussel shell biomass waste as an adsorbent: Equilibrium, kinetics, and thermodynamics, Journal of Taibah University for Science, 10(5), 664-674. 
Ertaş M., Acemioğlu B., Alma M.H. and Usta M. (2010), Removal of methylene blue from aqueous solution using cotton stalk, cotton waste and cotton dust, Journal of Hazardous Materials, 183(1), 421-427.

Extremera R., Pavlovic I., Pérez M. and Barriga C. (2012), Removal of acid orange 10 by calcined $\mathrm{Mg} / \mathrm{Al}$ layered double hydroxides from water and recovery of the adsorbed dye, Chemical engineering Journal, 213, 392-400.

Fan S., Tang J., Wang Y., Li H., Zhang H., Tang J., Wang Z. and Li X. (2016), Biochar prepared from co-pyrolysis of municipal sewage sludge and tea waste for the adsorption of methylene blue from aqueous solutions: Kinetics, isotherm, thermodynamic and mechanism, Journal of Molecular Liquids, 220(Supplement C), 432-441.

Gobi K., Mashitah M.D. and Vadivelu V.M. (2011), Adsorptive removal of Methylene Blue using novel adsorbent from palm oil mill effluent waste activated sludge: Equilibrium, thermodynamics and kinetic studies, Chemical Engineering Journal, 171(3), 1246-1252.

Gokce Y. and Aktas Z. (2014), Nitric acid modification of activated carbon produced from waste tea and adsorption of methylene blue and phenol, Applied Surface Science, 313(Supplement C), 352-359.

Gupta N., Kushwaha A.K. and Chattopadhyaya M.C. (2016), Application of potato (Solanum tuberosum) plant wastes for the removal of methylene blue and malachite green dye from aqueous solution, Arabian Journal of Chemistry, 9(Supplement 1), S707-S716.

Gupta V., Ali I. and Mohan D. (2003), Equilibrium uptake and sorption dynamics for the removal of a basic dye (basic red) using low-cost adsorbents, Journal of Colloid and Interface Science, 265(2), 257-264.

Gupta V., Suhas, Ali I. and Saini V. (2004), Removal of rhodamine $B$, fast green, and methylene blue from wastewater using red mud, an aluminum industry waste, Industrial and Engineering Chemistry Research, 43(7), 1740-1747.

Gupta V.K., Ali I., Saleh T.A., Nayak A. and Agarwal S. (2012), Chemical treatment technologies for waste-water recyclingan overview, RSC Advances, 2(16), 6380-6388.

Gupta V.K., Jain R., Mittal A., Saleh T.A., Nayak A., Agarwal S. and Sikarwar S. (2012), Photo-catalytic degradation of toxic dye amaranth on $\mathrm{TiO}_{2} / \mathrm{UV}$ in aqueous suspensions, Materials Science and Engineering: $C$, 32(1), 12-17.

Gupta V.K., Jain R., Nayak A., Agarwal S. and Shrivastava M. (2011), Removal of the hazardous dye-Tartrazine by photodegradation on titanium dioxide surface, Materials Science and Engineering: C, 31(5), 1062-1067.

GuptaV.K. and Nayak A. (2012), Cadmium removal and recovery from aqueous solutions by novel adsorbents prepared from orange peel and $\mathrm{Fe}_{2} \mathrm{O}_{3}$ nanoparticles, Chemical Engineering Journal, 180(Supplement C), 81-90.

Gupta V.K., Srivastava S.K. and Mohan D. (1997), Equilibrium uptake, sorption dynamics, process optimization, and column operations for the removal and recovery of malachite green from wastewater using activated carbon and activated slag, Industrial and Engineering Chemistry Research, 36(6), 2207-2218.

Gupta V.K., Srivastava S.K., Mohan D. and Sharma S. (1998), Design parameters for fixed bed reactors of activated carbon developed from fertilizer waste for the removal of some heavy metal ions, Waste Management, 17(8), 517-522.
Jain A., Gupta V. and Bhatnagar A. (2003), Utilization of ,ndustrial waste products as adsorbents for the removal of dyes, Journal of Hazardous Materials, 101(1), 31-42.

Jain A.K., Gupta V.K., Bhatnagar A. and Suhas (2003), A Comparative Study of Adsorbents Prepared from Industrial Wastes for Removal of Dyes, Separation Science and Technology, 38(2), 463-481.

Janoš P., Buchtová H. and Rýznarová M. (2003), Sorption of dyes from aqueous solutions onto fly ash, Water Research, 37(20), 4938-4944.

Kannan N. and Sundaram M.M. (2001), Kinetics and mechanism of removal of methylene blue by adsorption on various carbons-a comparative study, Dyes and pigments, 51(1), 25-40.

Karthikeyan S., Gupta V.K., Boopathy R., Titus A. and Sekaran G. (2012), A new approach for the degradation of high concentration of aromatic amine by heterocatalytic Fenton oxidation: Kinetic and spectroscopic studies, Journal of Molecular Liquids, 173(Supplement C), 153-163.

Kaur S., Rani S., Mahajan R.K., Asif M. and Gupta V.K. (2015), Synthesis and adsorption properties of mesoporous material for the removal of dye safranin: Kinetics, equilibrium, and thermodynamics, Journal of Industrial and Engineering Chemistry, 22, 19-27.

Khosravi I. and Eftekhar M. (2014), Na 0.5 Li 0.5 CoO 2 nanopowders: Facile synthesis, characterization and their application for the removal of methylene blue dye from aqueous solution, Advanced Powder Technology, 25(6), 1721-1727.

Kumar K.V. (2007), Pseudo-second order models for the adsorption of safranin onto activated carbon: comparison of linear and non-linear regression methods, Journal of hazardous materials, 142(1), 564-567.

Kurniawan A., Sutiono H., Indraswati N. and Ismadji S. (2012), Removal of basic dyes in binary system by adsorption using rarasaponin-bentonite: Revisited of extended Langmuir model, Chemical Engineering Journal, 189, 264-274.

Lee Y.-C., Kim E.J., Yang J.-W. and Shin H.-J. (2011), Removal of malachite green by adsorption and precipitation using aminopropyl functionalized magnesium phyllosilicate, Journal of Hazardous Materials, 192(1), 62-70.

Malash G.F. and El-Khaiary M.I. (2010), Methylene blue adsorption by the waste of Abu-Tartour phosphate rock, Journal of Colloid and Interface Science, 348(2), 537-545.

Meshko, V., L. Markovska, M. Mincheva and A. Rodrigues (2001), Adsorption of basic dyes on granular acivated carbon and natural zeolite, Water Research, 35(14), 3357-3366.

Mittal A., Krishnan L. and Gupta V. (2005), Removal and recovery of malachite green from wastewater using an agricultural waste material, de-oiled soya, Separation and Purification Technology, 43(2), 125-133.,

Mittal A., Mittal J., Malviya A. and Gupta V.K. (2009), Adsorptive removal of hazardous anionic dye "Congo red" from wastewater using waste materials and recovery by desorption, Journal of Colloid and Interface Science, 340(1), 16-26.

Mittal A., Mittal J., Malviya A. and Gupta V.K. (2010), Removal and recovery of Chrysoidine $Y$ from aqueous solutions by waste materials, Journal of Colloid and Interface Science, 344(2), 497-507. 
Muthukumar M., Sargunamani D., Selvakumar N. and Rao J.V. (2004), Optimisation of ozone treatment for colour and COD removal of acid dye effluent using central composite design experiment, Dyes and Pigments, 63(2), 127-134.

Muthukumaran C., Sivakumar V.M. and Thirumarimurugan M. (2016), Adsorption isotherms and kinetic studies of crystal violet dye removal from aqueous solution using surfactant modified magnetic nanoadsorbent, Journal of the Taiwan Institute of Chemical Engineers, 63, 354-362.

Namal O.O. and Kalipci E. (2017), Adsorption kinetics of methylene blue using alkali and microwave modified apricot stones, Journal of Environmental Chemical Engineering, DOI: 10.1016/j.jece.2017.11.061

Olgun A. and Atar N. (2009), Equilibrium and kinetic adsorption study of Basic Yellow 28 and Basic Red 46 by a boron industry waste, Journal of Hazardous Materials, 161(1), 148-156.

Özcan A.S., Erdem B. and Özcan A. (2004), Adsorption of Acid Blue 193 from aqueous solutions onto Na-bentonite and DTMAbentonite, Journal of Colloid and Interface Science, 280(1), 44-54.

Panizza M. and Cerisola G. (2008), Removal of colour and COD from wastewater containing acid blue 22 by electrochemical oxidation, Journal of Hazardous Materials, 153(1), 83-88.

Petrucci E., Di Palma L., Lavecchia R. and Zuorro A. (2015), Treatment of diazo dye Reactive Green 19 by anodic oxidation on a boron-doped diamond electrode, Journal of Industrial and Engineering Chemistry, 26, 116-121.

Rajendran S., Khan M.M., Gracia F., Qin J., Gupta V.K. and Arumainathan S. (2016), Ce ${ }^{3+}$-ion-induced visible-light photocatalytic degradation and electrochemical activity of $\mathrm{ZnO} / \mathrm{CeO}_{2}$ nanocomposite, Scientific Reports, 6, 31641.

Ramakrishna K.R. and Viraraghavan T. (1997), Use of slag for dye removal, Waste Management, 17(8), 483-488.

Saleh T.A. and Gupta V.K. (2012), Photo-catalyzed degradation of hazardous dye methyl orange by use of a composite catalyst consisting of multi-walled carbon nanotubes and titanium dioxide, Journal of Colloid and Interface Science, 371(1), 101-106.

Sanghi R. and Bhattacharya B. (2002), Review on decolorisation of aqueous dye solutions by low cost adsorbents, Coloration Technology, 118(5), 256-269.

Saravanan R., Karthikeyan N., Gupta V.K., Thirumal E., Thangadurai P., Narayanan V. and Stephen A. (2013), ZnO/Ag nanocomposite: An efficient catalyst for degradation studies of textile effluents under visible light, Materials Science and Engineering: C, 33(4), 2235-2244.

Saravanan R., Karthikeyan S., Gupta V.K., Sekaran G., Narayanan V. and Stephen A. (2013), Enhanced photocatalytic activity of $\mathrm{ZnO} / \mathrm{CuO}$ nanocomposite for the degradation of textile dye on visible light illumination, Materials Science and Engineering: C, 33(1), 91-98.

Serpen A., Ataç B. and Gökmen V. (2007), ,of Maillard reaction products from aqueous solutions and sugar syrups using adsorbent resin, Journal of Food Engineering, 82(3), 342-350.

Shakoor S. and Nasar A. (2016), Removal of methylene blue dye from artificially contaminated water using citrus limetta peel waste as a very low cost adsorbent, Journal of the Taiwan Institute of Chemical Engineers, 66(Supplement C), 154-163.

Sharma P., Kaur R., Baskar C. and Chung W.-J. (2010), Removal of methylene blue from aqueous waste using rice husk and rice husk ash, Desalination, 259(1), 249-257.
Sujka M. (2017), Ultrasonic modification of starch - Impact on granules porosity, Ultrasonics Sonochemistry, 37(Supplement C), 424-429.

Tang H., Zhou W. and Zhang L. (2012), Adsorption isotherms and kinetics studies of malachite green on chitin hydrogels, Journal of Hazardous Materials, 209-210, 218-225.

Wang Q., Ying T., Jahangir M.M. and Jiang T. (2012), Study on removal of coloured impurity in soybean oligosaccharides extracted from sweet slurry by adsorption resins, Journal of Food Engineering, 111(2), 386-393. 